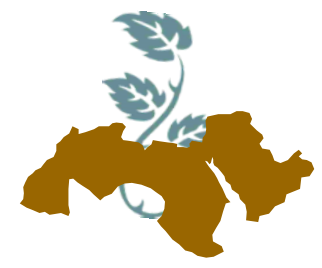

\title{
IMPACT OF BIOPOLYMERS ON ENHANCING SOIL PHYSICAL PROPERTIES
}

\author{
Sodaf, A. Ahmed'; Saad El-Dein'², A.A.; Enas, A. Hassan'; T.S. El-Tayeb1 \\ and Abd El-Hafez ${ }^{1}$, A.M. \\ 1- Agric. Microbiology Dept., Fac. of Agric., Ain Shams Univ., Cairo, Egypt \\ 2- Soil Sci. Dept., Fac. of Agric., Ain Shams Univ., Cairo, Egypt
}

Keywords: Biopolymer, Soil Conditioner, Soil Physics, Aggregate Soil Stability

\begin{abstract}
Light textured soils especially; sandy loam ones are the most dominant in the new reclaimed areas in Egypt. The main production constraints of this type of soil are low in organic carbon, porosity, stable aggregates, water retention capacity, and biological activities. Agriculture soil should have not only a good structure but also a good structure which can persist for a long time (e.g., a structure of high quality and stability). Soil aggregates are structural units of soil, which create complex pore systems controlling gas and water storage and fluxes in soil. Formation and stability of natural soil aggregates are affected by dozens of different factors and their individual effects are hardly distinguishable. Therefore, to observe more clear the mechanisms governing their water and mechanical stability, it was found necessary to study soil aggregates. In that sence, some studies showed encouraging findings of increasing soil stable aggregates due to using different soil conditioners. The objective of this work is to assess some extracellular polysaccharides biopolymers, i.e., Dextran, Alginate, Xanthan, Pullulan, and Curdlan, which were produced in our laboratory under the most suitable production conditions, to test their effects on the physical proprerties of soil taken from Toshka region at Aswan Governorate of Egypt. Data showed that soil porosity and MWD wet values have significant differences between all treatments and control under un-leaching processes. On the Other hand, in leaching processes, significant differences between all treatments and control were observed except in some treatments
\end{abstract}

that using lower ratios of Pullulan and Curdlan biopolymers (i. e. 0.4, 0.6 and $0.8 \%$ ).

Generally, the beneficial order of enhancement of aggregate stability was obtained with Dextran, followed by Alginate, Xanthan, Pullulan, and Curdlan.

\section{INTRODUCTION}

Varieties of exopolysaccharides (EPSs) are normally produced by a number of microorganisms such as extracellular or cell surface- attached material in the form of amorphous slime (Sutherland, 1998). These EPSs can be categorized as homopolysaccharides and heteropolysaccharides (Garcia-Ochoa, et al1995; Jorris and Vandamme, 1993). Homopolysaccharides are generally neutral glucans, while most of the heteropolysaccharides are polyanionic due to the presence of uronic acid. Microbial EPSs are propitious substitutes for the plant polysaccharides due to their unique and superior physical properties

Most bacteria are found as biofilms in soil, a complex aggregate of bacteria can be attached to the solid surface and embedded within a matrix of extracellular polymeric substances (EPS). EPS polysaccharides hold a primary role in maintaining the biofilm mechanical and structural stability (Flemming and Wingender, 2010). Typical molecular weights of positive charged extracellular polymeric substances (EPS) biopolymers ranged between $10^{3}$ to $10^{8} \mathrm{kDa}$ (Allison, 1998, and Sutherland, 2001). A number of microorganisms (bacteria, yeasts and fungi) can produce polysaccharides, depending on their subunit composition, structure and molecular mass. About 20 different types of microbial polysaccharides of commercial importance have been reported hitherto (Suther- 
land, 2001). Moreover, microbial polysaccharides were generally produced by the selected microbes under controlled fermentation conditions in stirred tank fermenters using complex media having high C: $N$ ratio (10: 1).

In soil, polysaccharides, as a whole, have received much attention because of a prominent role in soil aggregation (Lynch, 1985). One of the highly effective methods to improve soil structure is addition of conditioners such as synthetic and natural polymers that improve soil cohesion, porosity, maximum water holding capacity, and various beneficial soil properties.

Soil structure has traditionally been considered as one of the dominant attributes of soil quality, which critically influences the hydraulic properties, such as soil water retention curves (Bossuyt et al 2005; Jastrow et al 1996 and Lal, 2004). Although soil structure is not considered a factor directly related to crop production, it plays an important role in water and air supply to roots, root elongation, nutrient availability and macro fauna activity (Alexander et al $\mathbf{2 0 1 6}$ and Patricia et al 2016)

Water stable aggregates are structural units within the soil organized as micro- $(<250 \mathrm{~mm})$ and macro-aggregates $(>250 \mathrm{~mm}$ ) (Six et al 2004). The structure and stability of aggregates is crucial for water infiltration and movement, gas exchange (i.e. soil aeration), soil erosion, biological activity and rooting influencing the growth of crops (Hillel, 1998; Amézketa, 1999; Bronick and Lal, 2005 and $L I$ and FAN, 2014).

The structure is often measured by the stability of soil aggregates (Six et al 2000a; Bronick and Lal, 2005). Mean weight diameter (MWD) is a frequently applied parameter for aggregate stability quantification. Comparison of two MWD values related to the aggregate state before and after the applied test gave an estimation of the aggregate stability (Cosentino et al 2006, Castro Filho et al 2002, and Moncada et al 2013). High and sustainable soil aggregate stability is thus an important characteristic for soil physical quality (e.g. soil hydraulic and transport properties) preserving soil productivity and restraining soil erosion and degradation (Amézketa, 1999; Kodesova et al 2008; Castro Filho et al 2002 and Shrestha et al 2007). This has led to increased demands for the development of water-soluble polymeric soil conditioners, for example, Dextran and xanthan,which are commercially produced, and alginate, another potentially applicable exopolysaccharide as well as Curdlan.
The objective of this study is to find out the effect of extracellular polysaccharides produced by different microorganism differ in their chemical structure on the formation and stability of soil aggregates.

\section{MATERIALS AND METHODS}

To investigate the effect of produced extracellular polysaccharides on enhancing soil physical quality, e.g, the soil porosity and aggregates stability, surface comprehensive soil samples were collected from Toshka region at Aswan Governorate of Egypt to represent poor structural soils.

Forty hundred grams of soil were mixed individually with one of tested microbial polymers, using eight ratios of each polymer, i.e., 0.4, 0.6, 0.8, $1,1.5,2,3$, and 5 , forty treatments were applied with six replicates. Fresh water was added to all treatments until one a week, the water level was kept at field capacity of soil during this period by adding water back when lost $50 \%$ of water field capacity. After that, perforated plastic cans were divided into two groups. While the first group (120 cans) was subjected to same technique for three months. While the second group (120 cans) was subjected to excessive amount of water (i.e. leaching water) for three months.

The soil water-stable aggregates, really and bulk density, and porosity $(f \%)$ were determined before and after experiments.

\section{Extracellular biopolymeric Substances}

In this study, a range of extracellular polysaccharides, which naturally produced by the soil microbes, were used; pullulan from Aureobasidium pullulans.; curdlan from Rhizobium spp.; alginate from Azotobacter spp; xanthan, from Xanthomonas spp.; and dextran from Leuconostoc spp. These polysaccharides were produced in our laboratory under the most suitable production conditions.

\section{Soil sampling and characteristics}

Samples were gently crushed and sieved to $<2$ $\mathrm{mm}$. Physical, hydro-physical and chemical properties of soil samples were determined according to the standard methods described by Page (1982) and Klute (1986a), and are described in Table (1).

\section{Experimental technique}

To study the effect of different kinds and ratios of microbial polymers on the porosity and the 
stablilty of soil aggregates, incubation experiments were performed under open field conditions using perforated plastic cans, with inner diameter of 15 $\mathrm{cm}$ and height of $15 \mathrm{~cm}$, with filter paper at the bottom to prevent the soil from falling out of the column (Jalali and Merrikhpour, 2008).

Subtract between field capacity $\left(\theta_{\mathrm{FC}}\right)$, which equaled 0.17 and residual water $(\theta r)$ when $\Delta \theta / \Delta \mathrm{h}$ $=0$, which equaled 0.04 gave the difference of 0.13 which refered to the effective pores for transmit and holding water per unit volume $\left(\mathrm{cm}^{3}\right)$ after discharge water of soil (Saad El-Dein, 2013). This subtract represent the percentage of fresh water which is used for all treatments up to one week, the water level was kept at field capacity of soil during the whole by adding water when soil lose $50 \%$ of water field capacity. After that, perforated plastic cans were divided into two groups. The first group (120 cans) was subjected to the same techniqe for three months. The second group (120 cans was subjected also to the excessive amount of water ( e.g. leaching water) for three months. The quantity of leaching water was $3 \times \mathrm{V} \times\left(\theta_{\mathrm{FC}}-\right.$ $\theta r)$, where $V$ is the soil volume in the plastic cans.

Leaching processes technique was done to investigate the stability of different kinds and ratios of biopolymers on the soil by noticing the decrease in $M W D_{\text {wet }}$ values.

\section{Soil analyses after experiments}

At the end of the experimenters, soil samples were collected from perforated plastic cans. Particle and bulk density, porosity, aggregate size fractionation and stability testing of soil were determind (Mashhour, et al 2009).

\section{Aggregate size fractionation and stability test- ing}

The soil aggregates distribution of bulk soil was obtained by wet sieving (Haynes and Swift, 1990; Denef et al 2001; Klute, 1986b and Yoder, 1936). This study was focused on macro-aggregates; that are particularly affected by agricultural use (Six et al 2000b. Four macro-aggregate fractions were studied after wet-sieving of the soils using $0.25,1$, 2, 5 and $10 \mathrm{~mm}$ mesh sieves. Micro-aggregate fractions were studied after wet-sieving the soils using less the $0.25 \mathrm{~mm}$ mesh sieves.

The percentage of water-stable aggregate (WSA) was calculated as shown in Eq. 1 as follows:

$$
\mathbf{W S A}=\mathbf{1 0 0} * \sum_{\mathbf{i}=\mathbf{n}}^{\mathrm{n}} \mathbf{M i}
$$

The aggregate mean weight diameter (MWD) was calculated as shown in Eq. 2 as follows:

MWD $=\sum_{\mathrm{i}=\mathbf{n}}^{\mathrm{n}} \mathrm{XiMi}$

Where: MWD is the mean-weight diameter of the WSA $(\mathrm{mm}), \mathrm{Xi}$ is the mean diameter of each size fraction $(\mathrm{mm}), \mathrm{Mi}$ is the proportion of the total WSA in the corresponding size fraction, $\mathrm{n}$ is the number of size fractions, and $i=1,2, \ldots, 5 \%$ (Manuel et al 2016; Xiaolei, et al 2016 and Jinsong, et al 2017)

\section{Statistical analysis}

The effect of different kinds and ratios of biopolymers on the porosity and the formation and stability of aggregates of soil were assessed by one-way ANOVA and the Tukey's multiple range tests at a level of significance of $P<0.05$ using Costat program (version 6.400) (Parihar, et al 2016 and Xiao, et al 2017).

\section{RESULTS AND DISCUSSIONS}

\section{Characteristic of soil sample}

Table (1) shows some physical and chemical properties of the studied soil sample. The obtained data indicated that the soil sample has sandy loam texture, high value of bulk density which equals $1.82 \mathrm{~g} / \mathrm{cm}^{3}$, low value of total porosity which equals $30.89 \%$, particle density of $2.63 \mathrm{~g} / \mathrm{cm}^{3}$. The percentage of organic matter and calcium carbonate content were very low. The soluble salts content was also low (less than $4.0 \mathrm{dS} / \mathrm{m}$ at $25^{\circ} \mathrm{C}$ ). Therefore, the soil sample is classified as nonsaline according to Richards, (1954).

\section{Soil porosity as affected by biopolymers}

The soil porosity $(\boldsymbol{f} \%)$ represents an index of the relative pore space. Traditionally $f \%$ is determined from the relationship between the soil bulk density $\left(\boldsymbol{\rho}_{\mathbf{b}}\right)$ and particle density $\left(\boldsymbol{\rho}_{\mathbf{s}}\right)$, (Barros et al 2016).

Data of the soil particle and bulk density, and porosity with and without leaching processes are shown in Table (2). Data indicated that by increasing in the used biopolymers ratio soil particle and bulk density were decreased. 
Table 1. Some physical and chemical properties of the studied soil sample

\begin{tabular}{|c|c|c|c|c|c|c|c|c|c|c|c|}
\hline \multicolumn{4}{|c|}{ * Particle size distribution \% } & \multirow[b]{2}{*}{$\begin{array}{c}\text { Texture } \\
\text { class }\end{array}$} & \multirow[b]{2}{*}{$\begin{array}{c}\rho_{\mathrm{s}} \\
\mathrm{g} / \mathrm{cm}^{3}\end{array}$} & \multirow[b]{2}{*}{$\begin{array}{c}\rho_{\mathrm{b}} \\
\mathrm{g} / \mathrm{cm}^{3}\end{array}$} & \multirow[b]{2}{*}{$f \%$} & \multirow[b]{2}{*}{$\begin{array}{l}\text { OM } \\
\%\end{array}$} & \multirow[b]{2}{*}{$\mathrm{CaCO}_{3} \%$} & \multirow[b]{2}{*}{$\begin{array}{l}{ }^{* *} E c_{e} \\
(\mathrm{dS} / \mathrm{m})\end{array}$} & \multirow{2}{*}{$\underset{\text { (peste) }}{\mathrm{PH}}$} \\
\hline Clay & Silt & $\begin{array}{l}\text { Fine } \\
\text { Sand }\end{array}$ & $\begin{array}{c}\text { Coarse } \\
\text { Sand }\end{array}$ & & & & & & & & \\
\hline 17.85 & 2.17 & 34.72 & 45.26 & $\begin{array}{l}\text { Sandy } \\
\text { Loam }\end{array}$ & 2.63 & 1.82 & 30.89 & 0.09 & 2.42 & 0.36 & 7.97 \\
\hline
\end{tabular}

Each value is the mean of three replicates. $\boldsymbol{\rho}_{\mathbf{s}}$ is the Particle density.

$\boldsymbol{\rho}_{\mathrm{b}}$ is the Bulk density. $f \%$ is the percentage of porosity.

* According to ISSS classification. ${ }^{* *}$ Electrical conductivity at $25^{\circ} \mathrm{C}$ in soil paste extract.

Table 2. Effect of adding different rations of biopolymers on soil porosity before and after leaching processes.

\begin{tabular}{|c|c|c|c|c|c|c|c|}
\hline \multirow{2}{*}{ Tret. } & \multirow{2}{*}{$\%$} & \multicolumn{3}{|c|}{ without leaching } & \multicolumn{3}{|c|}{ with leaching } \\
\hline & & $\rho_{\mathrm{s}} \mathrm{g} / \mathrm{cm}^{3}$ & $\rho_{b} \mathrm{~g} / \mathrm{cm}^{3}$ & $f \%$ & $\rho_{\mathrm{s}} \mathrm{g} / \mathrm{cm}^{3}$ & $\rho_{\mathrm{b}} \mathrm{g} / \mathrm{cm}^{3}$ & $f \%$ \\
\hline Control & 0.0 & 2.57 & 1.82 & $29.3 \mathrm{a}$ & 2.58 & 1.89 & $26.6 \mathrm{a}$ \\
\hline \multirow{8}{*}{ 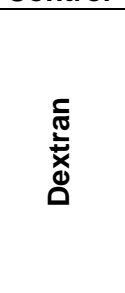 } & 0.4 & 2.62 & 1.80 & $31.2 \mathrm{~g}$ & 2.66 & 1.88 & $29.3 \epsilon$ \\
\hline & 0.6 & 2.62 & 1.80 & $31.2 \mathrm{~g}$ & 2.63 & 1.86 & $29.3 \epsilon$ \\
\hline & 0.8 & 2.61 & 1.79 & $31.2 \mathrm{~g}$ & 2.57 & 1.82 & $29.3 \epsilon$ \\
\hline & 1.0 & 2.59 & 1.78 & $31.2 \mathrm{~g}$ & 2.51 & 1.78 & $29.3 \epsilon$ \\
\hline & 1.5 & 2.59 & 1.77 & $31.8 \mathrm{i}$ & 2.44 & 1.72 & $29.3 \epsilon$ \\
\hline & 2.0 & 2.62 & 1.77 & $32.3 \mathrm{i}$ & 2.47 & 1.70 & $31.2 \mathrm{~g}$ \\
\hline & 3.0 & 2.70 & 1.76 & $34.9 \mathrm{j}$ & 2.40 & 1.65 & $31.2 \mathrm{~g}$ \\
\hline & 5.0 & 2.71 & 1.76 & $34.9 \mathrm{j}$ & 2.37 & 1.63 & $31.2 \mathrm{~g}$ \\
\hline \multirow{8}{*}{ 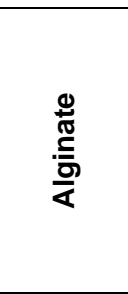 } & 0.4 & 2.61 & 1.80 & $30.9 \mathrm{f}$ & 2.66 & 1.90 & $28.6 \mathrm{c}$ \\
\hline & 0.6 & 2.60 & 1.80 & $30.9 \mathrm{f}$ & 2.63 & 1.87 & 28.60 \\
\hline & 0.8 & 2.59 & 1.79 & $30.9 \mathrm{f}$ & 2.56 & 1.83 & $28.6 \mathrm{c}$ \\
\hline & 1.0 & 2.59 & 1.78 & $31.3 \mathrm{~g}$ & 2.50 & 1.79 & $28.7 \mathrm{de}$ \\
\hline & 1.5 & 2.57 & 1.76 & $31.4 \mathrm{gh}$ & 2.46 & 1.75 & $29.1 \epsilon$ \\
\hline & 2.0 & 2.58 & 1.77 & $31.4 \mathrm{gh}$ & 2.43 & 1.72 & $29.1 \epsilon$ \\
\hline & 3.0 & 2.57 & 1.75 & $31.8 \mathrm{i}$ & 2.43 & 1.69 & $30.5 f$ \\
\hline & 5.0 & 2.57 & 1.76 & $31.8 \mathrm{i}$ & 2.39 & 1.66 & $30.5 f$ \\
\hline \multirow{8}{*}{ 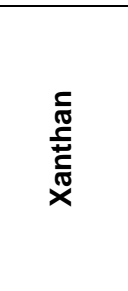 } & 0.4 & 2.59 & 1.80 & $30.4 \mathrm{~b}$ & 2.59 & 1.90 & $26.6 a$ \\
\hline & 0.6 & 2.59 & 1.81 & $30.4 \mathrm{~b}$ & 2.65 & 1.89 & $28.6 \mathrm{c}$ \\
\hline & 0.8 & 2.63 & 1.81 & $30.9 \mathrm{f}$ & 2.63 & 1.88 & 28.60 \\
\hline & 1.0 & 2.63 & 1.81 & $30.9 \mathrm{f}$ & 2.59 & 1.85 & $28.6 \mathrm{c}$ \\
\hline & 1.5 & 2.63 & 1.80 & $31.4 \mathrm{gh}$ & 2.57 & 1.82 & $29.1 d e$ \\
\hline & 2.0 & 2.63 & 1.80 & $31.4 \mathrm{gh}$ & 2.51 & 1.78 & $29.1 d e$ \\
\hline & 3.0 & 2.63 & 1.80 & $31.6 \mathrm{~h}$ & 2.53 & 1.77 & $30.2 \epsilon$ \\
\hline & 5.0 & 2.63 & 1.80 & $31.6 \mathrm{~h}$ & 2.50 & 1.75 & $30.2 \epsilon$ \\
\hline \multirow{8}{*}{$\frac{\frac{5}{3}}{\frac{\bar{J}}{3}}$} & 0.4 & 2.59 & 1.80 & $30.4 \mathrm{~b}$ & 2.59 & 1.90 & $26.6 a$ \\
\hline & 0.6 & 2.59 & 1.80 & $30.4 \mathrm{~b}$ & 2.58 & 1.90 & $26.6 a$ \\
\hline & 0.8 & 2.59 & 1.80 & $30.4 \mathrm{~b}$ & 2.58 & 1.89 & 26.6 \\
\hline & 1.0 & 2.59 & 1.80 & $30.7 \mathrm{~d}$ & 2.58 & 1.88 & 27.2 \\
\hline & 1.5 & 2.59 & 1.80 & $30.7 \mathrm{~d}$ & 2.54 & 1.85 & $27.2 \mathrm{~b}$ \\
\hline & 2.0 & 2.57 & 1.78 & $30.7 \mathrm{~d}$ & 2.49 & 1.81 & 27.2 \\
\hline & 3.0 & 2.59 & 1.78 & $31.2 \mathrm{~g}$ & 2.54 & 1.80 & $29.1 b c$ \\
\hline & 5.0 & 2.59 & 1.78 & $31.2 \mathrm{~g}$ & 2.51 & 1.78 & $29.1 \mathrm{bc}$ \\
\hline \multirow{8}{*}{$\begin{array}{l}\frac{5}{\frac{\pi}{0}} \\
\frac{0}{3} \\
0\end{array}$} & 0.4 & 2.59 & 1.80 & $30.4 \mathrm{~b}$ & 2.59 & 1.90 & 26.6 \\
\hline & 0.6 & 2.59 & 1.80 & $30.4 \mathrm{~b}$ & 2.58 & 1.90 & 26.6 \\
\hline & 0.8 & 2.59 & 1.81 & $30.4 \mathrm{~b}$ & 2.58 & 1.89 & 26.6 \\
\hline & 1.0 & 2.60 & 1.80 & $30.7 \mathrm{~d}$ & 2.59 & 1.88 & $27.2 \mathrm{~b}$ \\
\hline & 1.5 & 2.59 & 1.80 & $30.7 \mathrm{~d}$ & 2.56 & 1.86 & $27.2 \mathrm{~b}$ \\
\hline & 2.0 & 2.59 & 1.80 & $30.7 \mathrm{~d}$ & 2.54 & 1.85 & $27.2 b$ \\
\hline & 3.0 & 2.59 & 1.79 & 30.8de & 2.54 & 1.83 & 27.9 \\
\hline & 5.0 & 2.58 & 1.79 & 30.8de & 2.53 & 1.82 & 27.90 \\
\hline
\end{tabular}

Each value is the mean of three replicates.

Means having the same letter in each separate column are not significantly different at the $5 \%$ level according to LSDtest. 
These led to increase soil porosity. The soil porosity data showed significant differences between all treatments and control with un-leaching processes experiments, since treatments designated by the same letter are not significant at the $5 \%$ level according to LSD-test. The beneficial order of enhancement of aggregate stability was Dextran, Alginate, Xanthan, Pullulan, and Curdlan, respectively. On the Other hand, in leaching processes experiments, there were significant differences between all treatments and control except with those treatments using lower ratios of Pullulan and Curdlan biopolymers, (i .e. $0.4,0.6$ and $0.8 \%$ ).

\section{Stability and size distribution of soil aggre- gates}

Data of the aggregate size distribution without leaching processes are shown in Tables 3 and their $M W D_{\text {wet }}$ are shown in Figure 1. Mean weight diameter (MWD) is a frequently applied parameter for aggregate stability quantifica-tion. Comparison between the aggregates state before and after the applied test can give an estimation of the aggregate stability (Moncada et al 2013). Therefore, data indicated by increasing biopolymer ratio soil aggregates stability increased.

Table 3. Distribution and stability of aggregates as affected by different treatments without leaching processes

\begin{tabular}{|c|c|c|c|c|c|c|c|}
\hline \multirow{3}{*}{ No } & \multirow{3}{*}{ polymer } & \multirow{3}{*}{ Tret. } & \multicolumn{5}{|c|}{ Aggregates diameters $(\mathrm{mm})$} \\
\hline & & & $<0.25$ & $0.25-1$ & $1-2$ & $2-5$ & $5-10$ \\
\hline & & & \multicolumn{5}{|c|}{ Distribution of aggregate fractions (\%) } \\
\hline 1 & Cont. & 0 & 51.48 & 34.46 & 12.50 & 1.36 & 0.20 \\
\hline 2 & \multirow{8}{*}{ 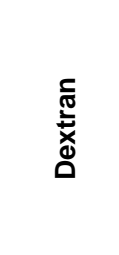 } & 0.4 & 44.07 & 36.98 & 15.22 & 2.36 & 1.37 \\
\hline 3 & & 0.6 & 42.23 & 37.69 & 16.23 & 2.65 & 1.20 \\
\hline 4 & & 0.8 & 47.80 & 32.25 & 15.00 & 3.30 & 1.65 \\
\hline 5 & & 1 & 47.47 & 33.23 & 14.23 & 3.78 & 1.29 \\
\hline 6 & & 1.5 & 43.36 & 34.56 & 15.26 & 4.23 & 2.59 \\
\hline 7 & & 2 & 37.46 & 37.69 & 16.16 & 4.69 & 4.00 \\
\hline 8 & & 3 & 38.54 & 33.56 & 18.92 & 4.56 & 4.42 \\
\hline $\mathbf{9}$ & & 5 & 41.70 & 29.26 & 19.92 & 4.68 & 4.44 \\
\hline 10 & \multirow{8}{*}{ 言 } & 0.4 & 44.39 & 38.39 & 15.69 & 1.23 & 0.30 \\
\hline 11 & & 0.6 & 37.30 & 43.33 & 17.65 & 1.29 & 0.43 \\
\hline 12 & & 0.8 & 49.91 & 29.52 & 17.66 & 1.89 & 1.02 \\
\hline 13 & & 1 & 43.24 & 35.60 & 18.22 & 1.90 & 1.04 \\
\hline 14 & & 1.5 & 55.14 & 25.60 & 13.27 & 3.90 & 2.09 \\
\hline 15 & & 2 & 55.50 & 25.20 & 13.31 & 3.89 & 2.10 \\
\hline 16 & & 3 & 52.07 & 26.33 & 14.25 & 4.09 & 3.26 \\
\hline 17 & & 5 & 52.81 & 25.40 & 14.36 & 4.10 & 3.33 \\
\hline 18 & \multirow{8}{*}{ 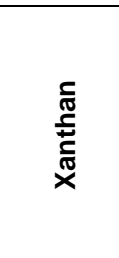 } & 0.4 & 51.36 & 32.33 & 15.50 & 0.58 & 0.23 \\
\hline 19 & & 0.6 & 53.97 & 30.33 & 14.26 & 1.02 & 0.42 \\
\hline 20 & & 0.8 & 56.52 & 23.39 & 16.99 & 1.58 & 1.52 \\
\hline 21 & & 1 & 56.89 & 23.33 & 16.66 & 1.60 & 1.52 \\
\hline 22 & & 1.5 & 55.84 & 24.44 & 16.59 & 1.53 & 1.60 \\
\hline 23 & & 2 & 57.53 & 23.33 & 15.22 & 2.03 & 1.89 \\
\hline 24 & & 3 & 53.87 & 26.66 & 15.20 & 2.22 & 2.05 \\
\hline 25 & & 5 & 54.24 & 27.10 & 14.23 & 2.33 & 2.10 \\
\hline 26 & \multirow{8}{*}{$\frac{\frac{5}{0}}{\frac{\bar{J}}{3}}$} & 0.4 & 52.73 & 30.23 & 16.21 & 0.59 & 0.24 \\
\hline 27 & & 0.6 & 50.49 & 33.33 & 15.23 & 0.62 & 0.33 \\
\hline 28 & & 0.8 & 50.21 & 33.66 & 15.11 & 0.67 & 0.35 \\
\hline 29 & & 1 & 50.28 & 33.26 & 15.23 & 0.78 & 0.45 \\
\hline 30 & & 1.5 & 49.81 & 34.27 & 14.23 & 0.91 & 0.78 \\
\hline 31 & & 2 & 46.69 & 37.59 & 13.59 & 1.11 & 1.02 \\
\hline 32 & & 3 & 49.68 & 33.02 & 14.59 & 1.26 & 1.45 \\
\hline 33 & & 5 & 50.52 & 34.56 & 11.59 & 1.45 & 1.88 \\
\hline 34 & \multirow{8}{*}{$\begin{array}{l}\frac{5}{\pi} \\
\frac{0}{0} \\
\bar{J}\end{array}$} & 0.4 & 52.87 & 30.22 & 16.05 & 0.61 & 0.25 \\
\hline 35 & & 0.6 & 51.37 & 32.36 & 15.28 & 0.65 & 0.34 \\
\hline 36 & & 0.8 & 51.38 & 32.33 & 15.29 & 0.65 & 0.35 \\
\hline 37 & & 1 & 50.12 & 33.74 & 15.11 & 0.67 & 0.36 \\
\hline 38 & & 1.5 & 47.86 & 35.66 & 15.33 & 0.78 & 0.37 \\
\hline 39 & & 2 & 45.85 & 36.66 & 16.23 & 0.88 & 0.38 \\
\hline 40 & & 3 & 49.51 & 33.34 & 15.66 & 1.01 & 0.48 \\
\hline 41 & & 5 & 49.37 & 32.33 & 16.69 & 1.10 & 0.51 \\
\hline
\end{tabular}

Each value is the mean of three replicates. 


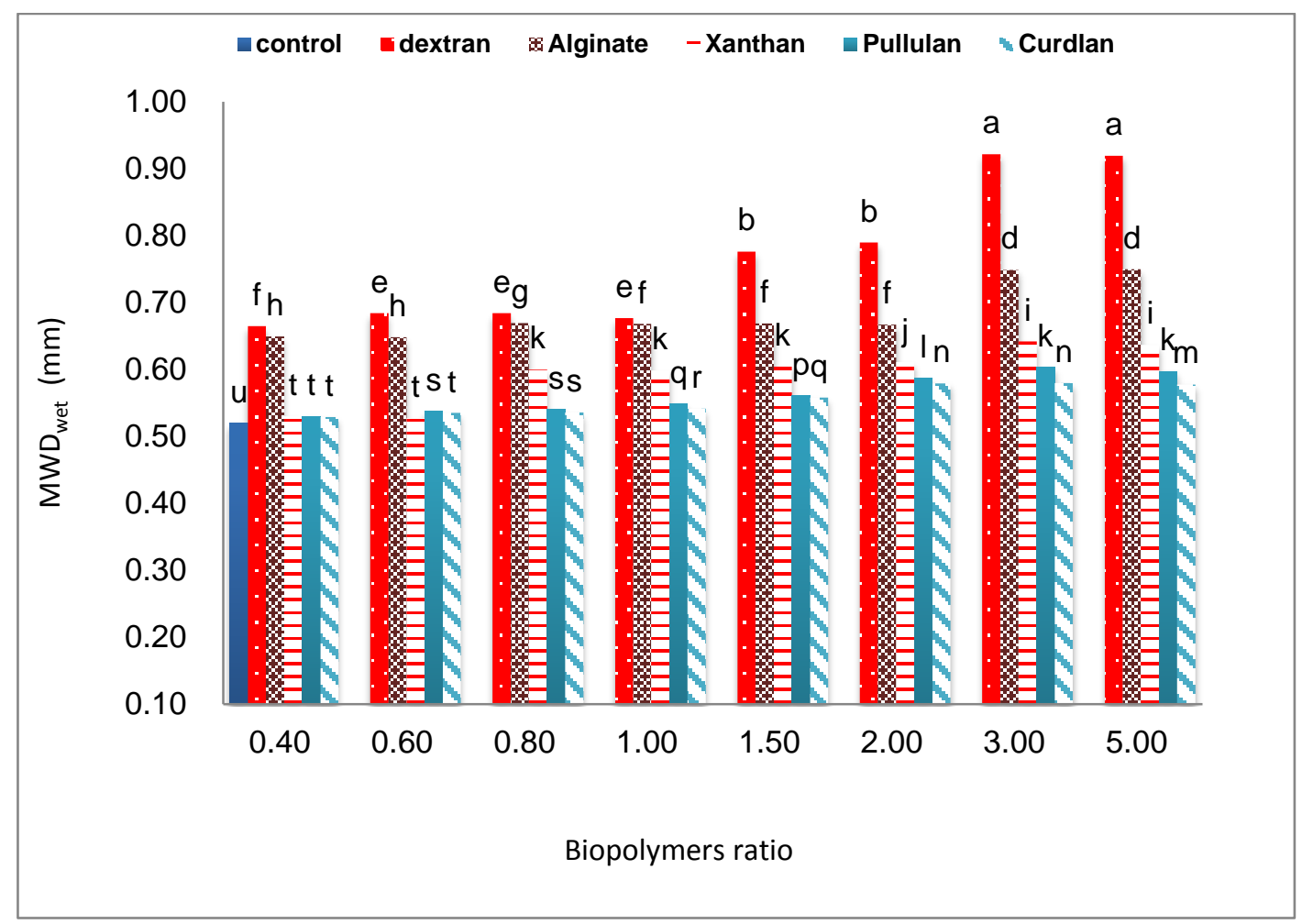

Fig. 1. Mean Weight Diameter (MWD) of soil aggregates stability without leaching processes as affected by biopolymers .

The $M W D_{\text {wet }}$ showed significant differences between all treatments and control, which means that designated treatments by the same letter are not significant at the $5 \%$ level according to LSD-test. The beneficial order of enhancement of aggregate stability was Dextran, Alginate, Xanthan, Pullulan, and Curdlan, respectively. These results may be attributed to the effect of organic matter content of microbial biomass and microbial byproducts including cell wall residues and extracellular polysaccharides (Mashhour, et al, 2009). In addition, data of the aggregate size distribution with leaching processes are shown in Tables 4 and their MWD wet are shown in Figure 2. Data indicated that the significant differences between all treatments and control were obtined except with some treatments using the lowest ratios of Pullulan and Curdlan biopolymers (i. e. $0.4,0.6$ and $0.8 \%$ ).

\section{Stability of biopolymers}

The aim of leaching processes experiments to detect the polymers stability against water, in other words, determinate losing of polymer with adding excessive water more than field capacity which has impact on stability of new formatted aggregates. Detection of losing was conducted by the decreasing in both $\mathrm{MWD}_{\text {wet }}$ and soil aggregates.

The results of ANOVA for data are shown in Table 2. and Figure 2. and indicated that leaching processes had significant differences between all treatments and control except with some treatments that using the lowest ratios of Pullulan and Curdlan biopolymer (i. e. $0.4,0.6$ and $0.8 \%$ ) and slight decrease in the rest treatments except dextran treatments. 


\section{CONCLUSION}

Use of some biopolymers can raise soil quality by enhancing soil physical properties (i. e. the soil porosity and aggregates). The beneficial order of enhancement of soil quality was Dextran, Alginate, Xanthan, Pullulan, and Curdlan, respectively without continuous leaching processes but with continuous leaching it is not recommended to was the low percentage of Pullulan, and Curdlan.

Table 4. Distribution and stability of aggregates as affected by different biopolymers with leaching processes

\begin{tabular}{|c|c|c|c|c|c|c|c|}
\hline \multirow{3}{*}{ No } & \multirow{3}{*}{ polymer } & \multirow{3}{*}{ Tret. } & \multicolumn{5}{|c|}{ Aggregates diameters (mm) } \\
\hline & & & $<0.25$ & $0.25-1$ & $1-2$ & $2-5$ & $5-10$ \\
\hline & & & \multicolumn{5}{|c|}{ Distribution of aggregate fractions (\%) } \\
\hline 1 & & 0 & 53.13 & 33.23 & 12.22 & 1.22 & 0.20 \\
\hline 2 & & 0.4 & 52.86 & 33.33 & 11.22 & 1.23 & 1.36 \\
\hline 3 & & 0.6 & 55.08 & 30.30 & 12.01 & 1.23 & 1.38 \\
\hline 4 & $\bar{\pi}$ & 0.8 & 46.97 & 36.66 & 13.40 & 1.45 & 1.52 \\
\hline 5 & $\underset{\mathrm{d}}{\breve{x}}$ & 1 & 47.79 & 35.23 & 13.89 & 1.54 & 1.55 \\
\hline 6 & & 1.5 & 46.07 & 37.89 & 12.12 & 1.89 & 2.03 \\
\hline 7 & & 2 & 47.18 & 36.60 & 12.21 & 1.91 & 2.10 \\
\hline 8 & & 3 & 38.43 & 38.89 & 15.55 & 3.80 & 3.33 \\
\hline 9 & & 5 & 40.38 & 25.48 & 30.21 & 2.15 & 1.78 \\
\hline 10 & & 0.4 & 50.56 & 35.55 & 12.36 & 1.20 & 0.33 \\
\hline 11 & & 0.6 & 52.49 & 33.17 & 12.30 & 1.56 & 0.48 \\
\hline 12 & 䒕 & 0.8 & 54.03 & 31.64 & 12.23 & 1.52 & 0.58 \\
\hline 13 & $\frac{5}{5}$ & 1 & 50.53 & 34.42 & 12.25 & 2.02 & 0.78 \\
\hline 14 & $\frac{1}{4}$ & 1.5 & 52.46 & 31.23 & 13.10 & 2.20 & 1.01 \\
\hline 15 & & 2 & 53.53 & 30.33 & 12.58 & 2.33 & 1.23 \\
\hline 16 & & 3 & 52.28 & 30.00 & 13.22 & 3.02 & 1.48 \\
\hline 17 & & 5 & 58.17 & 23.66 & 12.59 & 3.33 & 2.25 \\
\hline 18 & & 0.4 & 53.00 & 33.23 & 12.22 & 1.32 & 0.23 \\
\hline 19 & & 0.6 & 52.78 & 33.33 & 12.11 & 1.50 & 0.28 \\
\hline 20 & 폳 & 0.8 & 53.31 & 32.30 & 12.26 & 1.68 & 0.45 \\
\hline 21 & $\bar{E}$ & 1 & 50.61 & 35.36 & 11.11 & 2.03 & 0.89 \\
\hline 22 & $\ddot{x}$ & 1.5 & 51.86 & 34.00 & 11.12 & 2.00 & 1.02 \\
\hline 23 & & 2 & 47.59 & 37.60 & 11.36 & 2.22 & 1.23 \\
\hline 24 & & 3 & 47.85 & 37.00 & 11.50 & 2.21 & 1.44 \\
\hline 25 & & 5 & 48.90 & 35.66 & 11.65 & 2.33 & 1.46 \\
\hline 26 & & 0.4 & 51.51 & 33.33 & 14.23 & 0.65 & 0.28 \\
\hline 27 & & 0.6 & 51.65 & 33.33 & 14.02 & 0.70 & 0.30 \\
\hline 28 & $\frac{\bar{\pi}}{3}$ & 0.8 & 52.66 & 32.30 & 14.02 & 0.68 & 0.34 \\
\hline 29 & 昙 & 1 & 52.85 & 32.20 & 13.80 & 0.80 & 0.35 \\
\hline 30 & $\overline{0}$ & 1.5 & 49.24 & 35.02 & 14.50 & 0.65 & 0.59 \\
\hline 31 & & 2 & 51.28 & 34.25 & 12.23 & 1.63 & 0.61 \\
\hline 32 & & 3 & 47.89 & 37.36 & 12.13 & 1.77 & 0.85 \\
\hline 33 & & 5 & 47.52 & 37.40 & 12.46 & 1.78 & 0.85 \\
\hline 34 & & 0.4 & 48.92 & 38.00 & 12.23 & 0.56 & 0.29 \\
\hline 35 & & 0.6 & 48.09 & 38.69 & 12.30 & 0.60 & 0.32 \\
\hline 36 & ত্ & 0.8 & 49.33 & 37.25 & 12.30 & 0.69 & 0.43 \\
\hline 37 & 일 & 1 & 49.25 & 37.20 & 12.45 & 0.78 & 0.32 \\
\hline 38 & $\overline{0}$ & 1.5 & 48.02 & 38.60 & 12.36 & 0.60 & 0.42 \\
\hline 39 & & 2 & 47.55 & 38.60 & 12.60 & 0.71 & 0.54 \\
\hline 40 & & 3 & 53.33 & 31.64 & 13.33 & 1.01 & 0.69 \\
\hline 41 & & 5 & 54.66 & 29.26 & 14.20 & 1.10 & 0.78 \\
\hline
\end{tabular}

Each value is the mean of three replicates. 


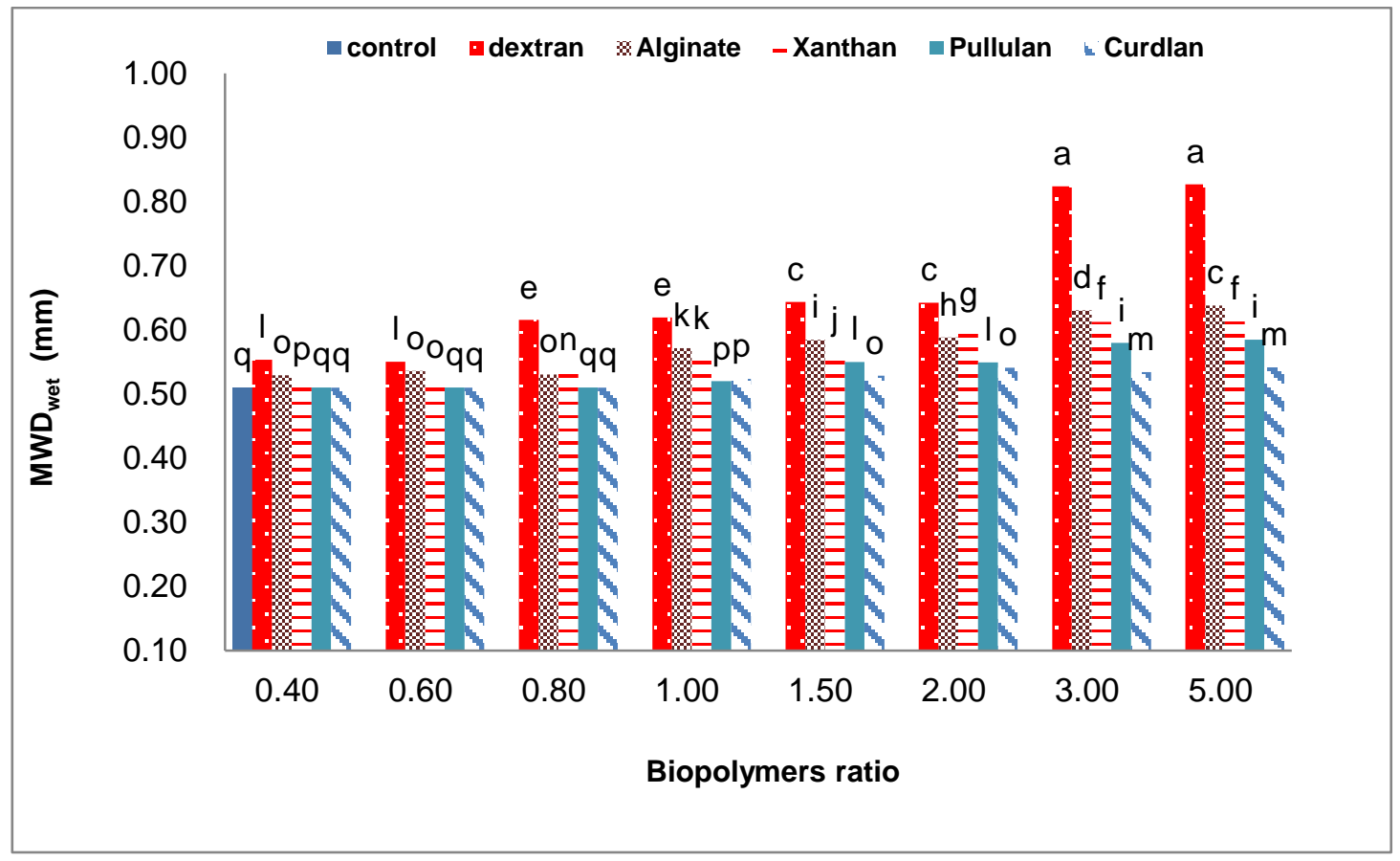

Fig. 2. Mean Weight Diameter (MWD) of soil aggregates with leaching processes as affected by biopolymers.

\section{REFERENCES}

Alexander, B.V., Vladimir, A.K., Natalya, A.K., Olga, I.P., Sergey, A.P., Elena, V.L., Aksana, M.P., Kirk, H. and Irina, V.P. 2016. Salinized humic substances act as hydrophobic modifiers of soil separates inducing formation of waterstable aggregates in soils. Catena 137, 229236.

Allison, D.G. 1998. Exopolysaccharide production in bacterial biofilm. Biofilm J., 3, 1-19.

Amézketa, E. 1999. Soil aggregation and porosity in relation to contents of free iron oxide and clay. Soil Sci., 101, 164- 170.

Arca, M.N., Weed, S.B. 1966. Soil aggregation and porosity in relation to contents of free iron oxide and clay. Soil Sci., 101, 164-170.

Barros, J.L., Thiers, O. and Torres, F. 2016. Feasibility study of estimating the porosity of soils from sound absorption measurements. Measurement 77, 213- 221.

Bossuyt, H.; Six, J. and Hendrix, P.F. 2005. Protection of soil carbon by microaggregates within earthworm casts. Soil Biol. Biochem., 37, 251- 258.

Bronick, C.J. and Lal, R. 2005. Soil Structure and management: A review. Geoderma 124, 3.
Castro Filho, C., Lourenço, A., Guimarães, M.D.F. and Fonseca, I. 2002. Aggregate stability under different soil management systems in a red latosol in the state of Parana, Brazil. Soil Tillage Res., 65, 45- 51.

Cosentino, D., Chenu, C. and Le Bissonais, Y. 2006. Aggregate stability and microbial community dynamics under drying-wetting cycles in silt loam soil. Soil Biol. Biochem., 30, 20532062.

Denef, K., Six, J., Paustian, K. and Merckx, R. 2001. Importance of macroaggregate dynamics in controlling soil carbon stabilization: shortterm effects of physical disturbance induced by dry-wet cycles. Soil Biol. Biochem., 33, 21452153.

Flemming, H.C. and Wingender, J. 2010. The biofilm matrix Nat. Rev. Microbial., 8, 623633.

Garcia-Ochoa, F., Santos, V. and Alcon, A. 1995. Xanthan gum production: An unstructured kinetic model. Enzyme and Microbial Technology 17, 206- 217.

Haynes, R. and Swift, R. 1990. Stability of soil aggregates in relation to organic constituents and soil water content. J. Soil Sci., 41, 73- 83.

Hillel, D. 1998. Environmental Soil Physics: Fundamentals, Applications, and Environmen- 
tal Considerations. Academic Press Inc., San Diego, USA.

Jalali, M. and Merrikhpour, H. 2008. Effects of poor quality irrigation waters on the nutrient leaching and groundwater quality from sandy soil. Sina University, Hamadan, Iran. Environ. Geol., 53, 1289-1298.

Jastrow, J.D., Boutton, T.W. and Miller, R.W. 1996. Carbon dynamics of aggregateassociated organic matter estimated by carbon13 natural abundance. Soil Sci. Soc. Am. J., 60, 801- 807.

Jinsong, Z., Shan, C., Ronggui, H. and Yayu, L. 2017. Aggregate stability and size distribution of red soils under different land uses integrally regulated by soil organic matter, and iron and aluminum oxides. Soil \& Tillage Research 167, 73- 79.

Jorris, K. and Vandamme, E.J. 1993. Novel production and applications aspects of bacterial cellulose. Microbiology 1, 27- 29.

Klute, A. 1986a. Methods of Soil Analysis. Part 1: Physical and Mineralogical Methods. Methods of Soil Analysis. Part. Physical and Mineralogical Methods pp. 413- 423.

Klute, A. 1986b. Water retention: Laboratory methods. In A. Klute (ed.) Methods of Soil Analysis. Part 1.2 nd ed., Agronomy Monogr. 9. ASA and SSSA, Madison, WI., USA, pp. 635662.

Kodesova, R., Kocarek, M., Kodec, V., Simunek, J. and Kozak, J. 2008. Impact of soil micromorphological features on water flow and herbicide transport in soils. Vadose Zone J., 7, 798-809.

Lal, R. 2004. Soil carbon sequestration impacts on global climate change and food security. Science 304, 1623-1627.

LI, G. and FAN, H. 2014. Effect of Freeze-Thaw on Water Stability of Aggregates in a Black Soil of Northeast China. Soil Sci. Society of China 24, 285- 290.

Lynch, J.M. 1985. Polysacchariden synthesis by capsular microorganisms in coculture with cellulytic fungi on straw and stabilization of soil aggregates. Biology and Fertility of Soil 1, 161-166.

Mashhour, A.M., Rizk, A.H. and Abdel-Hady, E.S. 2009. Soil properties as affected by incubation of Blue-green Algae. Egypt. J. Soil Sci., 49, 359- 368.

Manuel, A.E., Manuel, C.C. and Remigio, P.N. 2016. Poorly-crystalline components in aggre- gates from soils under different land use and parent material. Catena 144, 141-150.

Moncada, M.P., Gabriels, D., Cornelis, W. and Lobo, D. 2013. Comparing aggregate stability tests for soil physical quality indicators. Land Degradation \& Development Wiley Online Library.

Page, A.L. 1982. Methods of soil Analysis, Part 2. "Chemical and Microbiological", Page, A.L. (ed), Agronomy Monograph No.9., $\mathbf{2}^{\text {nd }}$ ed., Am. Soc., of Agron., Madison, Wisc., USA.

Parihar, C.M., Yadav, M.R., Jat, S.L., Singh, A.K., Kumar, B., Pradhan, S., Chakraborty, D., Jat, M.L., Jat, R.K., Saharawat, Y.S. and Yadav, O.P. 2016. Long term effect of conservation agriculture in maize rotations on total organic carbon, physical and biological properties of a sandy loam soil in north-western IndoGangetic Plains. Soil \& Tillage Research 161, 116- 128.

Patricia, J.P., Jorge, M.S., Victoria, Arcenegui A., Rafael, Delgado, Juan, M.M., Elena, L., Lorena, M. Z. and Antonio, J. 2016. Advances in the knowledge of how heating can affect aggregate stability in Mediterranean soils: a XDR and SEM-EDX approach. Catena 147, 315- 324.

Richards, L.A. 1954. "Diagnosis and Improvement of saline and alkali soils". US. Dept Agric. Handbook 60.

Saad El-Dein, A.A. (2013). Studies on reclamation requirements to minimize soil salinity. Ph.D. thesis. Fac. Agric., Ain Shams. Univ., Cairo, Egypt.

Shrestha, B.M., Singh, B.R., Sitaula, B.K., Lal, R. and Bajracharya, R.M. 2007. Soil aggregate and particle associated organic carbon under different land uses in Nepal. Soil Sci. Soc. Am. J., 71, 1194-1199.

Six, J., Elliott, E.T. and Paustian, K. 2000a. Soil macroaggregate turnover and microaggregate formation: a mechanism for $\mathrm{C}$ sequestration under no-tillage agriculture. Soil Biol. Biochem., 32, 2099-2103.

Six, J., Elliott, E.T. and Paustian, K. 2000b. Soil structure and soil organic matter II. A normalized stability index and the effect of mineralogy. Soil Sci. Soc. Am. J., 64, 1042-1049.

Six, J., Bossuyt, H., Degryze, S. and Denef, K. 2004. A history of research on the link between (micro) aggregates soil biota, and soil organic matter dynamics. Soil Tillage Res., 79, 7- 31. 
Sutherland, I.W. 1998. Novel and established applications of microbial polysaccharides. Trends in Biotechnology, 16, 41- 46.

Sutherland, I.W. 2001. Biofilm Exopolysaccharides: A strong and sticky framework. Microbiology 147, 3- 9.

Whiting, D., Card, A. and Wilson, C. 2010. Saline Soils. Colorado State University Extension, pp. 224- 229.

Xiao, I.Z., Jiang, T.L., Xiao, J.L., Yong, C.Y., Song, L., Paul, D.H., Michael, R.O. and Mu- hammad, N. 2017. Physical protection by soil aggregates stabilizes soil organic carbon under simulated $\mathrm{N}$ deposition in a subtropical forest of China. Geoderma 285, 323- 332.

Xiaolei, H., Hong, J., Yong, L., Yucui, M., Haiyan, T., Wei, R. and Qirong, S. 2016. The role of poorly crystalline iron oxides in the stability of soil aggregate-associated organic carbon in a rice-wheat cropping system. Geoderma 279, 1-10. 